\title{
Beekeeping Practice and Forest Conservation in Gwer-West Local Government Area of Benue State, Nigeria
}

\author{
Francis Sarwuan Agbidye*, Thompson Orya Hyamber \\ Department of Forest Production and Products, University of Agriculture, Makurdi, Nigeria
}

Email address:

fagbidye@yahoo.com (F. S. Agbidye)

\section{To cite this article:}

Francis Sarwuan Agbidye, Thompson Orya Hyamber. Beekeeping Practice and Forest Conservation in Gwer-West Local Government Area of Benue State, Nigeria. Agriculture, Forestry and Fisheries. Vol. 4, No. 5, 2015, pp. 222-227. doi: 10.11648/j.aff.20150405.14

\begin{abstract}
The research was conducted in Gwer West Local Government Area of Benue State, Nigeria as to ascertain the number of beekeepers in the area, identify the beekeeping methods used, the quantity of honey produced, the income generated, bee plants in the area, conservation methods used, and the challenges faced by beekeepers in the study area. Multi-stage and purposive sampling techniques were used to administer one hundred (100) copies of questionnaire in the study area as follows: 20 in Tsambe/Mbesev, 20 in Tyouhatiee/Injah, 15 in Gbaange/Tongov, 10 in Tijime, 12 in Avihijime, 15 in Nyamshii, and 8 in Meeikyeh respectively. The results showed that beekeepers exist in the study area with majority of them falling between the ages of 20 and 40 years and they use traditional methods of beekeeping. The study also revealed that the main reason for keeping bees in the study area was for income generation while the major challenge of beekeeping in the study area was pests. Majority (78\%) of the beekeepers produce about 40 litres of honey while a few (18\%) produce above 80 litres of honey annually generating between $\$ 28,000.00$ and $\$ 100,000.00$ (about 160 - 500USD) annually per beekeeper. The major bee plants in the study area were Daniellia oliveri, Citrus sinensis, and Mangifera indica while the major conservation methods used include deliberate retention of bee plants on farmlands, planting of bee plants in home gardens, fire tracing among others. It was recommended that training on modern beekeeping methods should be carried out in the study area to improve beekeeping practice in the study area.
\end{abstract}

Keywords: Beekeeping Practice, Beekeepers, Bee Plants, Forest Conservation, Home Gardens

\section{Introduction}

It has been stated that beekeeping is concerned with the practical management of the social species of honey bees, which live in large colonies of up to 100,000 individuals [1]. Beekeeping is usually carried out for the purpose of honey production and other hive products such as bees wax, pollen, propolis, royal jelly and bee venom and for the pollination of agriculture and other plants. The oriental or the African bee, Apis mellifera adansonii (Lestis) is the most widely used species in Africa for honey production [2]. According to [3], honey is the name given to the sweet, thick, liquid substance composed mainly of simple sugars produced by honey bees from the nectar of flowers. Honey bees collect nectar, transform and combine enzymatically with specific substances of their own and deposit in the cells of the honeycomb to mature. Honey has a taste that is distinctive from sugar and a nutritional value that is much higher than the latter [3]. Traditional beekeeping is practiced by various tribes all over the world, especially in the savannah regions. The practice relies on the wild honey bee colonies which are baited to the hives at the beginning or end of the raining season. Beekeeping is environmentally friendly and closely linked with other human activities [4]. It is an established fact that community forestry projects are strengthened by the involvement of beekeepers. This is so because beekeepers are experienced craftsmen and women with much knowledge and interest in what the forest and the trees produce. Beekeepers have knowledge of all the trees which are beneficial to bees and to humans. They know which of the trees are most preferred for nesting by the honey bees in the locality [5]. Bee plants are plants that are visited by bees either for nectar or pollen or both. Some plants provide only nectar while others provide only pollen and some provide both nectar and pollen. Some of the bee plants in Nigeria include the following: Ancardium occidentale (cashew), Mangifera indica (mango), Citrus spp (Orange), Elaeis guineensis (oil palm), Zea mays (maize or corn), Parkia biglobosa (Locust bean tree), Prosopis africana (Iron tree), Gmelina arborea, Azadirachta indica (Dogonyaro), Daniellia oliveri (African balsam), Chromolaena odorata (Siam weed, Vitellaria paradoxa (Shea 
butter tree), Tectona grandis (Teak), Khaya spp, Dacryodes edulis (African pear), Irvingia gabonensis (Bush mango) among others [5] and [6]. Forest conservation is recognized as the wise utilization, preservation and or renewal of forests, waters, lands and minerals for the greatest good of the people over a very long and endless period of time [7]. All over the world people have been known to conserve forest tree species that are of importance to them. Some of the ways that rural people conserve biodiversity is the deliberate retention of some trees [8]. Farmers in Benue State have been reported to deliberately maintain multipurpose forest trees on their farms for economic, social and ecological uses and thus encourage their conservation [9]. Some of these trees include Vitellaria paradoxa, Afzelia africana, Prosopis africana and Parkia biglobosa. Furthermore, [10] asserted that in Ethiopia, forest tree species like Schefflera abyssinica, and Croton macrostachyus are deliberately conserved by the rural people for beekeeping.

However, beekeeping practice is accessible to everybody and does not require serious academic knowledge and therefore anyone can engage in beekeeping irrespective of age [6]. Honey yield however, depends on the skills of beekeepers, climate, vegetation, and bee species [1]. Beekeeping is a sound economic activity which can be used for wealth creation and harnessed to tackle poverty problems in rural extension communities [5]. Honey production has not been appreciably exploited as to realize its perceived potential in Nigeria [5]. There is paucity of information on beekeeping activities in developing countries of the world especially Nigeria [5]. For instance; the amount of honey and other important hive products produced per annum as well as the number of beekeepers is hard to come by. This study was therefore carried out with the following objectives: (a) To determine the number of beekeepers in the study area (b) To identify the beekeeping methods used in the study area (c) To determine the quantity of honey produced and the income generated in the study area (d) To identify the major bee plants in the area and the conservation methods used for these plants and (e) To identify the challenges faced by beekeepers in the study area. This information is important in knowing the intervention measures to improve the beekeeping practice in the study area. The study was carried out in only seven of the fifteen council wards of the local government area.

\section{Methodology}

\subsection{The Study Area}

This study was conducted in Gwer West Local Government area (LGA) of Benue State. Gwer West LGA which was carved out of Gwer LGA in 1991 is located between latitudes 9 and $12^{0} \mathrm{~N}$ and longitudes 6 and $9^{\circ} \mathrm{E}$. It is bounded by Makurdi and Doma LGAs to the north, Gwer East LGA to east, Otukpo LGA to the South and Apa and Agatu LGAs to the West. The main inhabitants of the LGA area are the Tiv people. Gwer LGA has fifteen council wards namely; Sengev/Yengev, Saghev/Ukusu, Tsambe/Mbesev, Tyouhatiee/ Injah, Mbapa,
Tijime, Gambe/Ushin, Avihijime, Meeikyegh, Nyamshi, Ikyaghev, Gbaange/Tongov, Mbachohon, Mbabuande, Sengev. The headquarters of the LGA is Naka which is strategically located at killometre 40 along the Makurdi - Ankpa interstate road [11]. Gwer West LGA has annual rainfall of between $1500 \mathrm{~mm}$ and $2000 \mathrm{~mm}$. The rainy season starts in April and continues through October, with the highest peak in September. The LGA occupies a landmass of about $456.45 \mathrm{sq}$ $\mathrm{km}$. According to the 2006 census (projected figures for 2015), Gwer West LGA has a population of 154, 942 [12]. The soils of the study area are generally ferruginous in nature dominated by clay, loamy, and sandy with lateritic soils also occurring in nature. The vegetation of the study area is guinea savanna characterized by dense grass cover consisting of dominant species of trees like, Burkea africana, Daniellia oliveri, Khaya senegalensis, Prosopis africana, Azadirachta indica, Parkia biglobosa, Vitellaria paradoxa, Citrus spp, Tamarindus indica among others.

\subsection{Data Collection and Analyses}

The study was carried out in seven of the fifteen council wards of the LGA namely: Tsambe/Mbesev, Tyouhatiee/injah, Tijime, Avihijime, Meeikyegh, Nyamshi, Gbaange/Tongon. The study population comprised some of the beekeepers in the LGA. The sample size of 100 was drawn from 135 beekeepers identified in the selected council wards. Following [13] with slight modifications, multi-stage sampling technique was adopted to select seven council wards out of fifteen. From each of the council wards selected, respondents (beekeepers) were purposely sampled for the study. Data for the study were collected using semi-structured questionnaire. The questionnaire was validated through a pre-test. The validated questionnaire was administered on 100 respondents in the seven selected Council wards as follows: 20 in Tsamba/Mbesev, 20 in Tyouhatiee/Injah, 15 in Gbaange/Tongov, 10 in Tijime, 12 in Avihijime, 15 in Nyamshii, and 8 in Meeikyeh. Data collected were analyzed using descriptive statistics (frequencies and percentages).

\section{Results}

\subsection{Socio - Economic Characteristics of Beekeepers in Gwer West LGA, Benue State, Nigeria}

The socio-economic characteristics of beekeepers (Table 1) showed that $98 \%$ percent of the beekeepers are male while only $2 \%$ are female. Majority of the beekeepers $(85 \%)$ are married are between 20 to 40 years (youths). A good percentage of the elderly (34\%) are also engaged in beekeeping. Most of the beekeepers are adherents of the Christian faith. The results also showed that majority of the beekeepers $(45 \%)$ have only primary education followed by those with no formal education (30\%). Majority of the beekeepers engage in farming as their primary occupation while $21 \%$ of the beekeepers do not engage in any other activity apart from beekeeping. 


\subsection{Reason for Practice Beekeeping}

The results obtained (Table 2) showed that respondents engaged in beekeeping mainly for income generation (86.0\%) while some do so because it was the profession of their forefathers $(11.0 \%)$ with and as a hobby (3.0\%).

\subsection{Duration of Beekeeping Practice in Gwer West LGA, Benue State, Nigeria}

The results obtained (Table 3 ) showed that majority of the beekeepers in the study area have been in the business for about 10 years $(56 \%)$ followed by those who have practiced beekeeping for about 5 years $(27 \%)$ while only $4 \%$ of the beekeepers have been in the practice for over 20 years $(4 \%)$.

\subsection{Training on Modern Beekeeping}

Information on Table 4 below showed that $98.0 \%$ of beekeepers are not trained into beekeeping while $2.0 \%$ are trained in beekeeping.

Table 1. Socio-economic characteristics of Beekeepers in Gwer West LGA, Benue State, Nigeria.

\begin{tabular}{|c|c|c|}
\hline Variable & Frequency & Percentage \\
\hline \multicolumn{3}{|l|}{ Sex } \\
\hline Male & 98 & 98.0 \\
\hline Female & 2 & 2.0 \\
\hline \multicolumn{3}{|l|}{ Marital Status } \\
\hline Single & 9 & 9.0 \\
\hline Married & 85 & 85.0 \\
\hline Divorced & 6 & 6.0 \\
\hline \multicolumn{3}{|l|}{ Age } \\
\hline Below 20 years & 6 & 6.0 \\
\hline $20-40$ years & 60 & 60.0 \\
\hline $41-60$ years & 34 & 34.0 \\
\hline \multicolumn{3}{|l|}{ Religion } \\
\hline Islam & 0 & 0.0 \\
\hline Christianity & 74 & 74.0 \\
\hline Traditional & 26 & 26.0 \\
\hline Non adherents & 0 & 0.0 \\
\hline \multicolumn{3}{|l|}{ Educational Status } \\
\hline No Formal Education & 30 & 30.0 \\
\hline Primary & 45 & 45.0 \\
\hline Secondary & 21 & 21.0 \\
\hline Tertiary & 4 & 4.0 \\
\hline \multicolumn{3}{|l|}{ Primary Occupation } \\
\hline Farming & 78 & 78.0 \\
\hline Beekeeping & 21 & 21.0 \\
\hline Trading & 1 & 1.0 \\
\hline Civil Service & 0 & 0.0 \\
\hline
\end{tabular}

Table 2. Reason for practicing beekeeping in Gwer West LGA, Benue State, Nigeria.

\begin{tabular}{lll}
\hline Reason & Frequency $(\mathbf{F})$ & Percentage $\mathbf{( \% )}$ \\
\hline Hobby & 3 & 3.0 \\
Source of income & 86 & 86.0 \\
Inheritance & 11 & 11.0 \\
Total & 100 & 100 \\
\hline
\end{tabular}

Table 3. Duration of Beekeeping Activity by Beekeepers in Gwer West LGA, Benue State, Nigeria.

\begin{tabular}{lll}
\hline Beekeeping practice (period) & Frequency $(\mathbf{F})$ & Percentage $(\mathbf{\%})$ \\
\hline 1-5 years & 27 & 27.0 \\
6-10 years & 56 & 56.0 \\
11-15 years & 13 & 13.0 \\
16-20 years & 0 & 0.0 \\
21 above & 4 & 4.0 \\
Total & 100 & 100 \\
\hline
\end{tabular}

Table 4. Training on Modern Beekeeping Practice in Gwer West LGA, Benue State, Nigeria.

\begin{tabular}{lll}
\hline Response & Frequency(F) & Percentage (\%) \\
\hline Yes & 2 & 2.0 \\
No & 98 & 98.0 \\
Total & 100 & 100 \\
\hline
\end{tabular}

Types of hives used by beekeepers in Gwer west LGA, Benue state, Nigeria.

The results of the study showed that all the beekeepers in the study area (100\%) used hollowed tree trunk hives for their beekeeping practice (Table 5, Plate 1).

Table 5. Types of Hives used by beekeepers in Gwer West LGA, Benue State, Nigeria.

\begin{tabular}{lll}
\hline Hive Used & Frequency(F) & Percentage (\%) \\
\hline Basket & 0 & 0.0 \\
Bamboo & 0 & 0.0 \\
Hollowed Tree Trunks & 100 & 100 \\
Clay Pots & 0 & 0.0 \\
Langstroth & 0 & 0.0 \\
Kenya top bar & 0 & 0.0 \\
Total & 100 & 100 \\
\hline
\end{tabular}
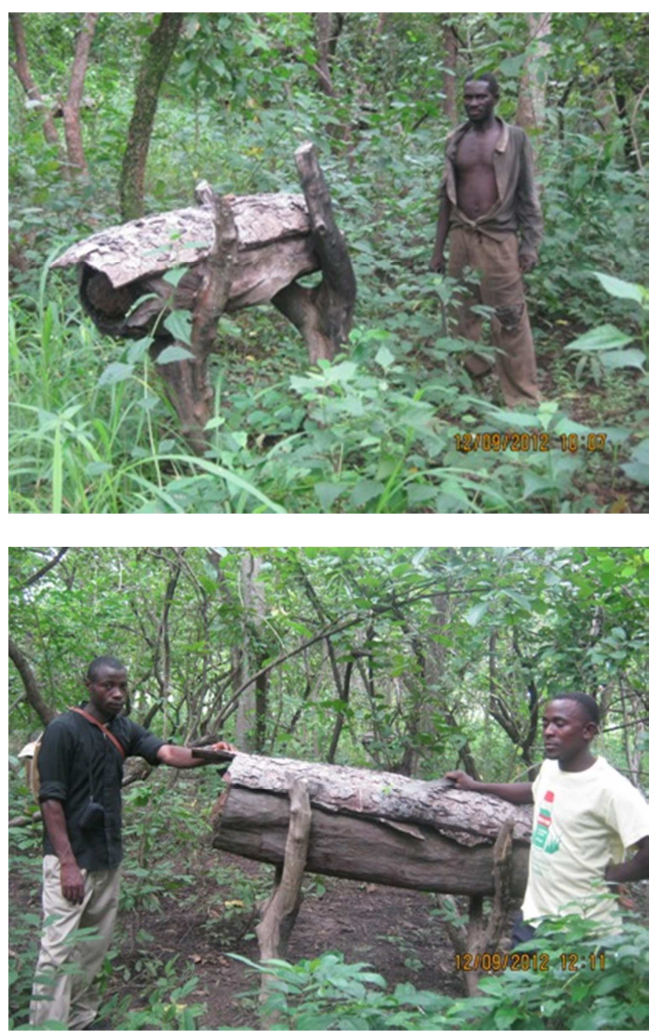

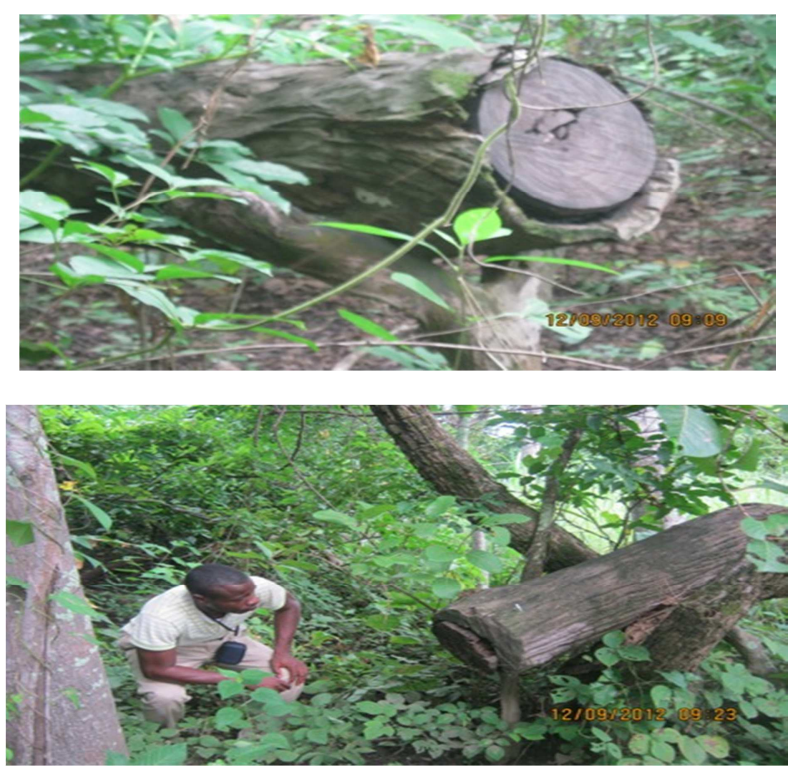

Plate 1. Hives used by beekeepers in Gwer West LGA, Benue State, Nigeria.

\subsection{Baiting Materials}

The result obtained (Table 6) showed that all the beekeepers drum the hollowed tree trunks to attract bees to the hives.

Table 6. Baiting materials used by beekeepers in the study area.

\begin{tabular}{lll}
\hline Baiting Materials & Frequency $(\mathbf{F})$ & Percentage $(\%)$ \\
\hline Tobacco leaf & 0 & 0.0 \\
Cow dung & 0 & 0.0 \\
Lemon grass & 0 & 0.0 \\
Drumming the hive & 100 & 100.0 \\
Total & 100 & 100 \\
\hline
\end{tabular}

\subsection{Location of Hives in the Study Area}

Results obtained (Table 7, Plate 1) showed that majority of the beekeepers $(90 \%)$ place their hives under trees while some do so on trees $(10 \%)$.

Table 7. Placement of Hives in the Study Area.

\begin{tabular}{lll}
\hline Placement of hive & Frequency(F) & Percentage (\%) \\
\hline On trees & 10 & 10.0 \\
Under Tree Shades & 90 & 90.0 \\
on the rock & 0 & 0.0 \\
Other & 0 & 0.0 \\
Total & 100 & 100 \\
\hline
\end{tabular}

\subsection{Obtaining Bee Colonies in the Study Area}

The results obtained (Table 8) showed that all the beekeepers in the study area obtained their bee colonies from the wild (nature).

Table 8. Obtaining Bee Colonies in the Study Area.

\begin{tabular}{lll}
\hline Colonizing Method & Frequency(F) & Percentage (\%) \\
Buying & 0 & 0.0 \\
Nature & 100 & 100 \\
Total & 100 & 100 \\
\hline
\end{tabular}

\subsection{Major Bee Plants in the Study Area}

The results obtained (Table 9) showed that the major bee plant in the study area was Daniellia oliveri (31.2\%) followed by Citrus sinensis (25\%).

Table 9. Major Bee Plants in the Study Area.

\begin{tabular}{lll}
\hline Bee Plant & Frequency(F) & Percentage (\%) \\
\hline Daniellia oliveri & 50 & 31.2 \\
Mangifera indica & 30 & 18.8 \\
Elaeis guineensis & 20 & 12.5 \\
Citrus sinensis & 40 & 25.0 \\
Parkia biglobosa & 20 & 12.5 \\
Total & 160 & 100 \\
\hline
\end{tabular}

\subsection{Forest Conservation Measures Adopted in the Study Area}

The results obtained showed that the beekeepers in Gwer-West LGA deliberately retain bee plants on their farm lands (40\%) and also plant bee plants in home gardens $(23.3 \%)$ among others measures to ensure their conservation (Table $10)$.

Table 10. Conservation measures adopted by beekeepers for bee plants in the Study area.

\begin{tabular}{lll}
\hline Conservation Method & Frequency(F) & Percentage (\%) \\
\hline $\begin{array}{l}\text { Deliberate retention of bee plants } \\
\text { on farmlands }\end{array}$ & 60 & 40.0 \\
$\begin{array}{l}\text { Fire tracing around bee plants } \\
\begin{array}{l}\text { Planting of bee plants in Home } \\
\text { gardens }\end{array}\end{array}$ & 30 & 20.0 \\
$\begin{array}{l}\text { Enlightenment campaigns } \\
\text { against bush burning }\end{array}$ & 15 & 23.3 \\
$\begin{array}{l}\text { Establishing plantations of bee } \\
\text { plants (Citrus) }\end{array}$ & 10 & 10.0 \\
Total & 150 & 6.7 \\
\hline
\end{tabular}

\subsection{Marketing Honey in the Study Area}

The result obtained (Table 11) showed that all the beekeepers $(100 \%)$ in the study area sell their honey in the local market (Naka Market).

Table 11. Marketing Channels for honey in the Study Area.

\begin{tabular}{lll}
\hline Marketing Channel & Frequency(F) & Percentage (\%) \\
\hline Honey Hawking & 0 & 0.0 \\
Local Market & 100 & 100 \\
Cooperative & 0 & 0.0 \\
Total & 100 & 100 \\
\hline
\end{tabular}

\subsection{Quantity of Honey Produced/Income Realized in the Study Area}

Results obtained (Table 12) showed that majority of beekeepers $(78.0 \%)$ in the study area produce below 40 litres followed by those who produce above 80 litres of honey in a year (18.0\%). Beekeepers make from 28,000.00 to 560,000 annually from selling honey. 
Table 12. Quantity of Honey Produced by Beekeepers in the Study Area.

\begin{tabular}{lll}
\hline Quantity (Litres) & Frequency (F) & Percentage (\%) \\
\hline$<40$ & 78 & 78.0 \\
$40-80$ & 4 & 4.0 \\
Above 80 & 18 & 18.0 \\
Total & 100 & 100 \\
\hline
\end{tabular}

\subsection{Problems Encountered by Beekeepers in the Study Area}

Results obtained from the study area on the problems encountered by beekeepers showed that the major problem is pest attack (85\%) followed by abscondment $(10 \%)$ and then low colonization $(5 \%)$.

Table 13. Problems Encountered by Beekeepers in the Study Area.

\begin{tabular}{lll}
\hline Problems & Frequency(F) & Percentage (\%) \\
\hline Pest attack & 85 & 85.0 \\
Disease & 0 & 0.0 \\
Fire Outbreak & 0 & 0.0 \\
Low Colonization & 5 & 5.0 \\
Abscondment & 10 & 10.0 \\
Theft & 0 & 0.0 \\
Total & 100 & 100 \\
\hline
\end{tabular}

\section{Discussion}

The results of this study have revealed that beekeeping is carried out in Gwer West LGA and that all categories of people; male, female, married, unmarried, divorced, young, middle aged, elderly, Christians, and adherents of traditional religion are all involved in beekeeping activities. Even though males were mostly involved, few women were also involved in the practice. Majority of the beekeepers were not involved in beekeeping as their primary occupation. This result agrees with [6] and [4] who stated that beekeeping practice can be combined with other human activities and the practice is accessible to everybody as it does not require serious academic knowledge and therefore anyone can engage in beekeeping irrespective of profession, age, sex, marital status, religion and educational background. It was also clear from the study that many people engage in beekeeping for income generation. This is in line with the results of [4], [5] and [6] who reported that beekeeping is a lucrative business and can bring extra income. It is very clear from the study that the beekeepers in Gwer West LGA have not received any form of training on modern beekeeping and hence engage only in traditional beekeeping methods with low outputs and hence low incomes. It had earlier been reported [6] that modern beekeeping training programmes have rarely been done by the government, non-governmental organizations (NGOs) and institutions. They advocated that if training programmes are carried out, beekeeping skills would be enhanced, number of beekeepers and productivity would increase leading to higher incomes from beekeeping. [1] had also reported that honey yield depends on the skills of beekeepers among other factors. The study also showed that
Gwer-West LGA has abundance of bee plants like Daniellia oliveri, Citrus sinensis, Mangifera indica, Parkia biglobosa, Elaeis guineensis among others which makes the area suitable for beekeeping practice. These bee plants found in Gwer-West LGA are similar to the ones reported by [6] and [5]. The beekeepers in the study area adopt various methods to conserve the bee plants in the area to ensure sustainability of their practice. These forest conservation methods include: deliberate retention of bee plants on farm lands, planting of bee plants in home gardens, fire tracing around bee plants, enlightenment campaigns against bush burning and establishment of plantations of bee plants especially Citrus sinensis and Elaeis guineensis. [9] and [8] had also reported deliberate retention of multipurpose forest trees on farmlands and also planting of in home gardens by farmers in Benue State for economic, social and ecological reasons thus ensuring their conservation. In Ethiopia, [10] reported that forest tree species like Schefflera abyssinica, and Croton macrostachyus are deliberately conserved by the rural people for beekeeping. The study also revealed that the major challenge facing beekeeping in Gwer West LGA is pest attack (ants). This problem could be solved by training and provision of relevant inputs.

\section{Conclusion and Recommendations}

The study has shown that a good number of the male population of Gwer West who have not received any form of training in modern beekeeping, engage in traditional beekeeping mainly for income generation. Beekeeping in the study area is mostly done by males as the two females involved inherited it from their late husbands. The major bee plant in Gwer-West LGA Daniellia oliveri while the major method of conserving bee plants is deliberate retention the plants on farmers' farmlands. Honey yield in Gwer West is low and all that is produced is sold at the local market Naka. The major challenge of beekeeping in the study area was pest attack (ants). Beekeeping practice in the study area has a lot of potential for income generation which can be harnessed to bring about significant improvement in the livelihood of the people, creation of job opportunities, and self empowerment scheme to the rural dwellers of Gwer-West Local Government area of Benue State. Since the people of Gwer West LGA do not engage in modern beekeeping practices, Government, NGOs, institutions and individuals should aid in providing an enabling environment to substantially increase level of honey production by training and providing the local beekeepers with modern beekeeping equipment for increased production.

\section{Acknowledgements}

The authors wish to acknowledge the contribution of the research assistants who helped with the administration of the questionnaires and the beekeepers in Gwer-West LGA for their cooperation in volunteering information for this research. 


\section{References}

[1] V. T. Leen, J. B. Willem, M. Marieke, S. Piet, and V. Hayo. Beekeeping in the tropics. Digigrafi Netherlands. 2005. pp749.

[2] C. D. Michener. The bees of the world. The John Hopkins University Press. Baltimore, MD, USA. 2000. pp. 913.

[3] R. T. Wilson. Current status and possibilities for improvement of traditional apiculture in sub-saharan Africa. Livestock Research for Rural Development. 2006. Vol. 13 (8) : 1-11.

[4] H. D. Usman. "The role of beekeeping in poverty alleviation". Magazine of the National Park Service, Nigeria. 2000. Pp. $43-44$

[5] A. A. Kareem, O. A, Iroko, A. F. Adio, O. C. Jegede, A. O. Olaitan and A. A. Jayeola. Role of non-timber forest products (NTFPS) in creating wealth: A case of honey production. In: L. Popoola, F. O. Idumah, V. A. J. Adekunle and I. O. Azeez (eds). The global economic crisis and sustainable renewable resources management. Proceedings of the $33^{\text {rd }}$ Annual Conference of the Forestry Association of Nigeria held in Benin City, Edo State, Nigeria, $25^{\text {th }}-29^{\text {th }}$ October, 2010 pp 429 - 435.

[6] A. A. Ukoima and U. F. Edeki. Apiculture: A panacea for poverty alleviation in the Niger delta, Nigeria. In: L. Popoola, F. O. Idumah, V. A. J. Adekunle and I. O. Azeez (eds). The global economic crisis and sustainable renewable resources management. Proceedings of the $33^{\text {rd }}$ Annual Conference of the Forestry Association of Nigeria held in Benin City, Edo State, Nigeria, $25^{\text {th }}-29^{\text {th }}$ October, 2010, pp 567-572.
[7] International Union for the Conservation of Nature (IUCN). Indigenous people and climate change/REDD-An overview of current discussions and main issues. 2010. Available at: http//cmsdata.iucn.org/downloads/iucn_briefing_ips_and_red d_march_2010.pdf. Retrieved October 15, 2011.

[8] T. N. Tee and A. Ageende. Community woodlot production as a sustainable forest management option in Benue State, Nigeria. In: Popoola, L and Oni, P. I. (eds.). Sustainable Forest Management in Nigeria- lessons and prospects. Proceeding of the 30th Annual FAN Conference held at Kaduna. 2005. pp 371-388.

[9] T. N. Tee and J. Amonum. Domestication of non-timber forest tree products for sustainable livelihood. Journal of Research in Agriculture 2008. 5 (4):76-81.

[10] K. Hundera. Traditional forest management practices in Jimma Zone, South West Ethiopia. Ethiopia Journal of Education and Science. 2007, 2 (2):1-9.

[11] Benue State Diary. Benue State of Nigeria Diary. Produced by the Ministry of Information and Culture Makurdi, Benue State, Nigeria. 2013.

[12] A. Tsee. The Dynamics of Benue State Population (1963-2016). Micro Teacher and Associates, Makurdi. 2013.91pp.

[13] F. S. Agbidye. Some Aspects of the Ecology, Nutritive Value and Marketability of Edible Forest Insects in Benue state, Nigeria. PhD. Thesis, Department of Forestry and Wood Technology, Federal University of Technology Akure, Nigeria. 2008. 118pp. 